\title{
Doeloriëntaties en het tijdsperspectief van oudere werknemers: is er een verband met pensioenintenties?
}

\author{
Maria Peeters, Bert Schreurs \& Jorg Damen*
}

\begin{abstract}
Deze studie heeft als doel de relaties te onderzoeken tussen werkgerelateerde temporele focus (d.w.z. gerichtheid op het professionele heden, verleden of de toekomst) en de motivatie van oudere werknemers om aan het werk te blijven tot aan de pensioensleeftijd. Hierbij veronderstellen we dat doeloriëntatie de relatie tussen temporele focus en pensioenintenties medieert. Aan dit onderzoek hebben 548 werknemers van 45 jaar en ouder deelgenomen. De resultaten laten zien dat een verledenfocus positief samenhangt met het stellen van leervermijdingsdoelen, terwijl een toekomstfocus positief samenhangt met leertoenaderingsdoelen. Het stellen van leertoenaderingsdoelen is positief gerelateerd aan de intentie om langer door te werken en het hebben van leervermijdingsdoelen negatief. Geconcludeerd wordt dat het stimuleren van een toekomstfocus in combinatie met een leertoenaderingsoriëntatie een belangrijke rol speelt bij het motiveren van ouderen om door te werken tot de pensioengerechtigde leeftijd.
\end{abstract}

\section{Inleiding}

\subsection{Introductie}

In Nederland ligt de gemiddelde pensioenleeftijd anno 2011 op 63 jaar (CBS, 2012). Dit betekent dat er nog steeds sprake is van een tendens om met vervroegd pensioen te gaan, dat wil zeggen, reeds voor de pensioengerechtigde leeftijd. In de Nationale Enquête Arbeidsomstandigheden (NEA) wordt sinds 2008 ook gevraagd of werknemers na hun 65ste willen blijven doorwerken. In 2010 gold dit slechts voor een kleine minderheid van de werknemers van 45 tot en met 64 jaar (15\%) (Koppes, De Vroome, Mol, Janssen \& Van den Bossche, 2011). Om het pensioenstelsel betaalbaar te kunnen houden, productiekracht te behouden en verlies van waardevolle kennis en ervaring door de uittreding van de babyboomgeneratie (het cohort dat geboren is tussen 1946-1964) tegen te gaan, moeten oudere werknemers tegenwoordig echter langer doorwerken dan hun 65ste (De Lange, Ybema \& Schalk, 2011; Frins, Van Ruysseveldt \& Syroit, 2011). Zo is het AOW-pensioen aangepast aan de stijgende levensverwachting (Rijksoverheid, 2011) en wordt het juridisch steeds makkelijker voor oudere werknemers om lan-

* Maria Peeters is verbonden aan de Universiteit Utrecht, vakgroep Sociale en Organisatiepsychologie. Correspondentieadres: Postbus 80140, 3508 TC Utrecht, tel. 030-2534822, e-mail m.peeters@uu.nl. Bert Schreurs is verbonden aan Maastricht University, School of Business and Economics. Jorg Damen was ten tijde van het onderzoek masterstudent bij de vakgroep Sociale en Organisatiepsychologie van de Universiteit Utrecht. 
ger door te werken (De Lange, Van der Heijden \& Peeters, 2013). Het is van cruciaal belang dat indien werknemers langer door moeten werken, ze ook een goed prestatie- en motivatieniveau behouden. Langer doorwerken impliceert per slot van rekening pas een toegevoegde waarde op de arbeidsmarkt als oudere medewerkers ook daadwerkelijk arbeidspotentieel hebben en behouden (De Graaf, Peeters \& Van der Heijden, 2011). Het volstaat dus niet om medewerkers via maatregelen louter te verplichten langer door te werken. Het is belangrijker om te begrijpen wat hen motiveert om met plezier aan de slag te blijven (Schalk et al., 2010; Zappala, Depolo, Fraccaroli, Guglielmi \& Sarchielli, 2008).

Eén factor die van invloed is op de motivatie van werknemers, is het tijdsperspectief dat zij hanteren (Karniol \& Ross, 1996). Tijdsperspectief verwijst in ruime zin naar de manier waarop mensen tijd beleven (Shipp, Edwards \& Lambert, 2009). Een fundamentele aanname in onderzoek naar tijdsperspectief is dat mensen verschillen in de mate waarin zij zich het verleden herinneren, het heden ervaren en anticiperen op de toekomst (Shipp et al., 2009). In deze studie onderzoeken we of, en zo ja hoe, het tijdsperspectief dat oudere werknemers hanteren, samenhangt met hun motivatie en daarmee de intentie om door te werken tot de pensioengerechtigde leeftijd (en dus niet met vervroegd pensioen te gaan).

Ondanks het afschaffen van allerlei aantrekkelijke pre-pensioenregelingen is het tijdstip van pensionering voor veel werknemers nog steeds een keuzemoment waar een zekere mate van beslissingsvrijheid aan ten grondslag ligt. Beehr (1986) beschrijft pensionering als een complex psychologisch besluitvormingsproces dat zich voltrekt over een langere periode en dat varieert tussen mensen naar gelang hun persoonlijke omstandigheden. Wang en Schultz (2010) categoriseren de predictoren van pensionering in (1) persoonlijke factoren en (2) werkgerelateerde factoren. In dit onderzoek besteden we aandacht aan factoren uit de eerste categorie. Daarnaast onderzoeken we of het type doelen dat werknemers hanteren (leervermijdingsdoelen versus leertoenaderingsdoelen), de relatie tussen het tijdsperspectief en de intentie om te blijven werken kunnen verklaren.

\subsection{Temporele focus}

'Tijdsperspectief' is een overkoepelend begrip dat verschillende tijdgerelateerde concepten bevat. Het drukt het globale beeld uit dat een persoon heeft ten opzichte van verschillende aspecten van tijd (Shipp et al., 2009). In dit onderzoek besteden we aandacht aan de temporele focus, een specifiek onderdeel van het globale tijdsperspectief van een individu (Shipp et al., 2009). Temporele focus gaat over de mate waarin individuen hun aandacht verdelen over het verleden, het heden of de toekomst (Bluedorn, 2002; Shipp et al., 2009). Het is een relatief stabiel persoonskenmerk dat beïnvloedt hoe mensen ervaringen van vroegere gebeurtenissen, huidige situaties en toekomstige verwachtingen verwerken in hun opvattingen, cognities, gedragingen en beslissingen. Het idee is dat mensen door onder andere hun opvoeding, de cultuur waarin ze leven en hun sociaaleconomische status een algemene en vrij stabiele geneigdheid ontwikkelen voor een bepaalde temporele focus, dus oftewel een geneigdheid om op de toekomst, het heden of het verleden gericht te zijn. Dit sluit niet helemaal uit dat de focus licht kan fluctueren over de tijd en dat mensen meerdere foci tegelijk kunnen heb- 
ben. Dat laatste duidt op het bestaan van een temporele focusprofiel. De zwakke positieve verbanden die worden aangetroffen tussen de drie temporele focusoriëntaties, bevestigen het bestaan van een dergelijk profiel (Shipp et al., 2009). Met het huidige onderzoek willen we meer te weten komen over de rol die temporele focus speelt in de werkcontext (d.w.z. 'werkgerelateerde temporele focus') en onderzoeken we óf, en hoe werkgerelateerde temporele focus samenhangt met de intentie van werknemers om tot aan hun pensioengerechtigde leeftijd te willen blijven werken.

Shipp en collega's beargumenteren dat temporele focus belangrijk is omdat de wijze van denken over het verleden, heden en de toekomst onze attitudes, beslissingen en gedrag beïnvloedt. Zo kan een verledenfocus ervoor zorgen dat werknemers piekeren over zaken uit het verleden, waardoor zij minder tevreden zijn met hun huidige situatie of een hogere verloopintentie hebben. Een verledenfocus kan echter ook het leren stimuleren indien uit eerdere ervaringen lering is getrokken. Op dezelfde wijze kunnen ook voorbeelden genoemd worden van positieve en negatieve consequenties van een heden- en toekomstfocus. Een viertal studies van Shipp en collega's laten echter zien dat mensen met een dominante oriëntatie op het verleden over het algemeen negatiever zijn. Zo hing verledenfocus positief samen met neuroticisme en negatieve affectiviteit, en was het negatief gerelateerd aan tevredenheid over het leven, optimisme en de perceptie van energiebronnen in het werk (d.w.z. autonomie, erkenning, mogelijkheden). Daarentegen bleek dat mensen met een dominante heden- of toekomstfocus positiever waren. Beide foci hingen bijvoorbeeld positief samen met tevredenheid over het leven, optimisme, conscientieusheid en positieve affectiviteit. De verwachting in het huidige onderzoek is dan ook dat de temporele focus op de volgende wijze samenhangt met pensioenintenties:

Hypothese 1a: Een werkgerelateerde toekomstfocus hangt positief samen met de intentie om door te werken tot aan de pensioenleeftijd.

Hypothese 1b: Een werkgerelateerde hedenfocus hangt positief samen met de intentie om door te werken tot aan de pensioenleeftijd.

Hypothese 1c: Een werkgerelateerde verledenfocus hangt negatief samen met intentie om door te werken tot aan de pensioenleeftijd.

\subsection{Temporele focus op het werk en het stellen van doelen}

Oorspronkelijk werd in het onderzoek naar doeloriëntaties de nadruk gelegd op twee typen doelen: leerdoelen en prestatiedoelen (De Lange, Van Yperen, Van der Heijden \& Bal, 2010; Elliot \& McGregor, 2001). Leerdoelen zijn gericht op de persoonlijke ontwikkeling van competenties door het eigen maken van taken. Hierbij vergelijken personen hun huidige prestaties met prestaties uit het verleden of met het beoogde beheersniveau van een taak (Elliot \& Church, 1997). Werknemers die leerdoelen hanteren, geloven dat inspanningen leiden tot succes, waardoor de aandacht van de werknemer vooral gericht is op de intrinsieke waarde van het leren zelf (Lee, McInerney, Liem \& Ortiga, 2010). Prestatiedoelen zijn echter gefocust op het demonstreren van de competentie ten opzichte van andere werknemers (Elliot \& McGregor, 2001). Werknemers die worden gedreven 
door prestatiedoelen, proberen door beter te presteren dan anderen hun gevoel van eigenwaarde te bevestigen (Lee et al., 2010) .

In dit onderzoek gaan we in op de rol van leerdoelen. Maehr en Kleiber (1981) stellen dat met het ouder worden de prestatiemotivatie verschuift van een meer extrinsiek competitief prestatiepatroon naar een meer intrinsiek leergerelateerd patroon. En wanneer de beperkte hoeveelheid onderzoek samengevat wordt, lijkt het dat oudere werknemers gekarakteriseerd kunnen worden door een sterkere focus op meer intrinsieke dan extrinsieke bekwaamheidseisen die voor een groter deel voortkomen uit de activiteiten zelf (leerdoelen) dan uit interpersoonlijke vergelijking van bekwaamheidseisen (prestatiedoelen) (Kanfer \& Ackerman, 2000; Maehr \& Kleiber, 1981).

Het dichotome model van leer- en prestatiedoelen is later door Elliot en Harackiewicz (1996) uitgebreid met een onderscheid in toenaderings- (focus op het verkrijgen van positieve of gewenste gebeurtenissen) en vermijdingsfocus (focus op het vermijden van negatieve of ongewenste gebeurtenissen) (Elliot \& Church, 1997; Elliot \& McGregor, 2001; Karniol \& Ross, 1996). In het huidige onderzoek wordt daarom ook het onderscheid gemaakt tussen leertoenaderings- en leervermijdingsdoelen. Werknemers met leertoenaderingsdoelen raken enthousiast voor een taak en zien deze als een uitdaging omdat ze graag willen leren. Werknemers met leervermijdingsdoelen werken echter uit angst om niet slechter te presteren dan voorheen (Elliot \& McGregor, 2001) en zijn bezorgd dat ze niet genoeg leren. $\mathrm{Zij}$ hebben dus een gerichtheid op leren om achteruitgang te vermijden.

De 'Socioemotional Selectivity Theory' (SST), een theorie over motivatie gedurende de levensloop (Carstensen, 2006; Carstensen, Isaacowitz \& Charles, 1999), stelt dat motivatie (en dus ook de motivatie om te werken) beïnvloed wordt door het subjectieve gevoel van de tijd die ons rest tot aan de dood. De subjectieve perceptie van de 'resterende tijd' zou diepgaande effecten hebben op basale processen als motivatie, emoties en cognities. De mate waarin, en hoe dit einde wordt waargenomen, wordt beïnvloed door de temporele focus van een werknemer. Als tijd als open wordt beschouwd (en dus meer gefocust wordt op de toekomst), dan zal de focus voornamelijk liggen op doelen die voorbereidend zijn, op het verwerven van kennis, het verbreden van de horizon en het stellen en nastreven van loopbaandoelen (Carstensen, 2006). Deze doelen komen overeen met leertoenaderingsdoelen (Elliot \& Church, 1997; Elliot \& McGregor, 2001; Lee et al., 2010). We verwachten dan ook dat er een positief verband is tussen een werkgerelateerde toekomstfocus en het hanteren van leertoenaderingsdoelen.

Werknemers met een dominante focus op het verleden zullen geneigd zijn de tijd tot aan het pensioen te zien als een gesloten periode, als 'een einde'. Ze blikken vaker terug op hun vroegere functioneren dan dat ze nadenken over toekomstig functioneren. De aandacht zal meer gericht zijn op het vinden van emotionele betekenis in het dagelijks leven in plaats van op het verzamelen van kennis, het verbreden van de horizon en het stellen en nastreven van doelen. Daarbij zijn ze gericht op het niet slechter presteren dan voorheen of het niet verliezen van hun vaardigheden, capaciteiten of geheugen (Elliot \& McGregor, 2001). Dit gedrag is kenmerkend voor leervermijding: de aandacht is gericht op het vermijden van uitingen van incompetentie. Onderzoek heeft aangetoond dat leervermijdings- 
doelen vaker voorkomen bij oudere dan bij jongere werknemers, en dat het de meest gehanteerde doelen zijn onder oudere werknemers (De Lange et al., 2010). In dit onderzoek verwachten we dat dit niet zozeer komt doordat de werknemer ouder is, maar doordat de temporele focus van ouderen in vergelijking met jongeren verschuift van een toekomst- naar een meer verledenfocus.

Voor wat betreft de mensen met een oriëntatie op het heden is de verwachting minder duidelijk. Omdat hypothese $1 \mathrm{~b}$ echter uitgaat van een positief verband tussen hedenfocus en pensioenintentie, verwachten we dat een hedenfocus positief samenhangt met het stellen van leertoenaderingsdoelen. Bovenstaande informatie wordt samengevat in de volgende hypothesen:

Hypothese 2a: Er is een positief verband tussen werkgerelateerde toekomstfocus en leertoenaderingsdoelen.

Hypothese $2 b$ : Er is een positief verband tussen werkgerelateerde hedenfocus en leertoenaderingsdoelen.

Hypothese 2c: Er is een positief verband tussen werkgerelateerde verledenfocus en leervermijdingsdoelen.

\subsection{Doeloriëntatie en de intentie om door te werken tot aan het pensioen}

Werknemers met leertoenaderingsdoelen vinden het betekenisvol bij te leren en zichzelf te ontwikkelen (Elliot, 2005). Ze willen zich verder bekwamen en hun bestaande competenties verbeteren. De plaats bij uitstek om competenties te ontwikkelen is de werkplek (hoewel sommige competenties natuurlijk ook buiten de arbeidstijd ontwikkeld kunnen worden). De leermogelijkheden binnen een werkcontext zijn legio en variëren van formele training en opleiding tot teambuilding en werkplekleren (Aguinis \& Kraiger, 2009). Omwille van de vele mogelijkheden tot zelfontwikkeling en persoonlijke groei zou de werkplek een aantrekkelijke en betekenisvolle plaats moeten zijn voor werknemers met leertoenaderingsdoelen.

Dit laatste lijkt veel minder het geval voor werknemers met leervermijdingsdoelen. De gedachte om minder goed te presteren dan voorheen boezemt deze werknemers angst in (Sideridis, 2008). Werknemers met leervermijdingsdoelen zien de werkplek niet als een plaats waar ze kunnen leren, maar juist als een plaats waarin de verschillen met eigen vroegere prestaties duidelijk zichtbaar worden (Baranik, Stanley, Bynum \& Lance, 2010). De kans dat prestaties afnemen, stijgt met de leeftijd en met het toenemen van fysieke en mentale beperkingen. Het is dan ook plausibel te veronderstellen dat de werkplek minder aantrekkelijk is voor oudere werknemers die leervermijdingsdoelen hanteren: door hun mindere werkprestaties worden ze voortdurend herinnerd aan de negatieve gevolgen van het ouder worden (Elliot \& Thrash, 2001).

Evidentie voor deze assumpties vinden we in het onderzoek van De Lange et al. (2010). Werknemers met leertoenaderingsdoelen scoorden het hoogst op bevlogenheid en sociale en persoonlijke betekenis van het werk, terwijl werknemers met leervermijdingsdoelen het laagst scoorden op deze uitkomsten. Deze informatie leidt tot de volgende hypothesen:

Hypothese 3a: Er is een positief verband tussen leertoenaderingsdoelen en de intentie om door te werken tot aan het pensioen. 
Hypothese 3b: Er is een negatief verband tussen leervermijdingsdoelen en de intentie om door te werken tot aan het pensioen.

\subsection{Doeloriëntatie als mediator}

Uit vroeger onderzoek blijkt dat het gehanteerde tijdsperspectief gevolgen heeft voor onder andere motivatie en gedrag (bijv. Carstensen, 2006; Karniol \& Ross, 1996; Simons, Vansteenkiste, Lens \& Lacante, 2004). In het huidige onderzoek veronderstellen we dat een werkgerelateerde heden- en toekomstfocus positief en een werkgerelateerde verledenfocus negatief samenhangen met de intentie om door te werken tot aan het pensioen (zie hypothese $1 \mathrm{a} t / \mathrm{m} 1 \mathrm{c}$ ). Meer specifiek verwachten we daarbij dat deze relaties verklaard worden door de doeloriëntatie van werknemers. Werknemers met een heden- en toekomstfocus willen doorwerken tot aan het pensioen omdat ze de mogelijkheid zien om bepaalde werkgerelateerde doelen na te streven en te bereiken (leertoenaderingsdoelen). Werknemers met een werkgerelateerde verledenfocus stellen in mindere mate specifieke en uitdagende loopbaandoelen. Ze vinden het bedreigend om vast te stellen dat de eigen prestaties afnemen (leervermijdingsdoelen). Hieruit volgen de volgende hypothesen:

Hypothese 4a: Leertoenaderingsdoelen mediëren de positieve relatie tussen toekomstfocus en de intentie om door te werken tot aan het pensioen.

Hypothese 4b: Leertoenaderingsdoelen mediëren de positieve relatie tussen hedenfocus en de intentie om door te werken tot aan het pensioen.

Hypothese 4c: Leervermijdingsdoelen mediëren de negatieve relatie tussen verledenfocus en de intentie om door te werken tot aan het pensioen.

\section{Methode}

\subsection{Procedure}

Aan dit onderzoek hebben werknemers van een Nederlandse universiteit en van een grote Nederlandse verzekeringsmaatschappij deelgenomen. Werknemers van 45 jaar en ouder ontvingen met goedkeuring van de betreffende $\mathrm{P} \& \mathrm{O}$-afdeling via hun werk-mail een uitnodiging om deel te nemen aan een vragenlijstonderzoek. De vragenlijst kon online worden ingevuld via Netquestionnaires en duurde ongeveer 20 tot 25 minuten. Deelname aan het onderzoek was geheel vrijwillig.

\subsection{Respondenten}

Binnen de verzekeringsmaatschappij werden willekeurig 500 werknemers van 45 jaar en ouder verzocht om deel te nemen aan het onderzoek. 223 (48.2\%) werknemers hebben de vragenlijst volledig ingevuld. Drie faculteiten van de universiteit werkten mee aan het onderzoek. De online vragenlijst werd naar alle werknemers ouder dan 45 jaar gestuurd. Van de 688 benaderde werknemers hebben er 325 (47.2\%) de vragenlijst volledig ingevuld. In totaal hebben dus 548 respondenten de vragenlijst volledig ingevuld. Alleen de volledig ingevulde vragenlijsten werden meegenomen in de analyse. 
In de steekproef van de verzekeringsmaatschappij was $44.8 \%$ vrouw. De minimumleeftijd was 45 jaar en de maximumleeftijd 64 jaar met een gemiddelde leeftijd van 51.9 jaar $(S D=4.3)$. Het grootste deel was samenwonend of getrouwd met $(28.3 \%)$ of zonder thuiswonende kinderen (50.2\%). Een kleiner deel was alleenstaand zonder (11.2\%) of met thuiswonende kinderen (7.2\%) of overig (3.1\%). Als hoogst genoten opleiding heeft $0.4 \%$ lagere school, $12.6 \%$ mavo, $15.2 \%$ havo, $4.9 \%$ vwo, $22.9 \%$ mbo, $27.8 \%$ hbo en $16.1 \%$ wo. Gemiddeld werkten de deelnemers 19.6 jaar $(S D=10.5)$ bij hun huidige organisatie en werkten ze 34.8 uur per week $(S D=6.8)$.

In de steekproef van de universiteit was $49 \%$ vrouw. De minimumleeftijd was 45 jaar en de maximumleeftijd 64 jaar met een gemiddelde leeftijd van 54.2 jaar $(S D=5.4)$. Het grootste deel was samenwonend of getrouwd met $(41.5 \%)$ of zonder thuiswonende kinderen (37.8\%). Een kleiner deel is alleenstaand zonder (12.6\%) of met thuiswonende kinderen (5.5\%) of overig (2.5\%). De steekproef bestond voor $61 \%$ uit wetenschappelijk personeel (WP) en voor $39 \%$ uit ondersteunend en beheerspersoneel (OBP). Als hoogstgenoten opleiding heeft $0.3 \%$ lagere school, $1.5 \%$ mavo, $3.4 \%$ havo, $2.2 \%$ vwo, $3.4 \%$ mbo, $15.4 \%$ hbo en $73.8 \%$ wo. Gemiddeld werkten de deelnemers 18.3 jaar $(S D=10.5)$ bij hun huidige organisatie. De samples zijn redelijk vergelijkbaar behalve met betrekking tot het opleidingsniveau. Mogelijke gevolgen hiervan worden besproken in de discussie.

\subsection{Meetinstrumenten}

Temporele focus is gemeten met acht items, ontleend aan de Temporal Focus Scale (TFS), ontwikkeld door Shipp et al. (2009). Voor het huidige onderzoek is een Nederlandse vertaling gebruikt, die door middel van een 'translation backtranslation' methode is vertaald vanuit de Engelstalige versie. Hierna zijn de items toegespitst op de werksituatie van de medewerker. Een voorbeelditem uit de toekomstschaal van TFS is 'Ik denk na over wat de toekomst me te bieden heeft'. In de temporele focus op de werkschaal (TFS-W) wordt dit item geformuleerd als 'Ik denk na over wat mijn professionele toekomst me te bieden heeft'. De TFS-W bestaat uit items die gedachten beschrijven over de tijdsperioden verleden (3 items), heden ( 2 items) en toekomst (3 items) (zie Bijlage A). De items werden gemeten op een 5 -puntsschaal $(1=$ nooit tot $5=$ vaak). De factoren hadden een matige tot goede betrouwbaarheid: verleden $(\alpha=.75)$, heden $(\alpha=.57)$, toekomst $(\alpha=.76)$.

Leertoenaderings- en leervermijdingsdoelen werden gemeten aan de hand van acht items, gebaseerd op de 'Achievement Goal Questionnaire' (AGQ, Elliot \& McGregor, 2001). Beide doelen werden gemeten aan de hand van vier items op een 5 -puntsschaal ( 1 = helemaal mee oneens tot 5 = helemaal mee eens). De items voor leertoenaderings- en leervermijdingsdoelen zijn voor het huidige onderzoek door middel van een 'translation back-translation' methode naar het Nederlands vertaald (zie Bijlage A). In tegenstelling tot de AGQ zijn de items toegespitst op de werksituatie en niet op de studiecontext. De factoren hadden een goede betrouwbaarheid: leertoenaderingsdoelen ( $\alpha=.79)$, leervermijdingsdoelen $(\alpha=.81)$.

De intentie om door te werken tot aan het pensioen is gemeten aan de hand van vier items, ontleend aan Van Dam, Van der Vorst en Van der Heijden (2009). Items 
werden gescoord op een 5-puntsschaal ( 1 = helemaal mee oneens tot 5 = helemaal mee eens). De respondenten hebben een sterkere intentie tot doorwerken tot aan het pensioen als ze een hogere score aangeven op de items. Een voorbeelditem is: 'Ik blijf aan de slag tot ik 65 ben'. Er is gekozen voor 65 jaar, omdat dat de pensioengerechtigde leeftijd was in Nederland op het moment dat de vragenlijst afgenomen werd. De schaalintentie om langer door te werken $(\alpha=.94)$ heeft een hoge betrouwbaarheid.

Controlevariabelen. Omdat dit onderzoek is afgenomen onder werknemers van twee verschillende organisaties, werd hiervoor in elke analyse gecontroleerd ( 0 = universiteit en 1 = verzekeringsmaatschappij). Ook werd gecontroleerd voor het geslacht van de werknemer $(0=$ man en $1=$ vrouw $)$, omdat het geslacht mogelijk een invloed heeft op (prestatie)motivatie (Meece, Glienke \& Burg, 2006) en pensioenintenties (Talaga \& Beehr, 1995). Verder is uit onderzoek gebleken dat de intentie om door te werken tot aan het pensioen wordt beïnvloed door de gezondheid (Boumans, De Jong \& Van der Linden, 2008; Talaga \& Beehr, 1989) en financiële situatie van de werknemer (Talaga \& Beehr, 1989). In de analyses met pensioenintentie als afhankelijke variabele zijn gezondheid en financiële situatie dan ook opgenomen als controlevariabelen. De financiële situatie is gemeten met 1 item van Zappala et al. (2008): 'In hoeverre is uw financiële situatie toereikend om eerder dan de pensioengerechtigde leeftijd met pensioen te kunnen gaan?' ( 1 = totaal niet toereikend; 7 = totaal toereikend). Gezondheid $(\alpha=.89)$ is gemeten aan de hand van een schaal van Adams en Beehr (1998), die bestaat uit vier items gemeten op een 5 -puntsschaal ( 1 = helemaal mee oneens tot 5 = helemaal mee eens). Een voorbeelditem is: 'Mijn gezondheid is beter dan die van de meeste mensen van mijn leeftijd'.

\subsection{Analyses}

Covariantie-structuuranalyses werden uitgevoerd door middel van LISREL 8.80 om de relaties te onderzoeken tussen temporele focus, leertoenaderings- en leervermijdingsdoelen en intentie om door te werken tot aan het pensioen. De analyses werden uitgevoerd volgens de twee-stappenbenadering van Anderson en Gerbing (1988): het meetmodel werd getoetst en vergeleken met alternatieve meetmodellen in stap 1 ; het structurele model werd getoetst en vergeleken met alternatieve structurele modellen in stap 2.

Het theoretische meetmodel bevatte de volgende latente constructen: verledenfocus, hedenfocus en toekomstfocus, leertoenaderings- en leervermijdingsdoelen, intentie om door te werken tot aan het pensioen, en gezondheid. Items fungeerden als indicatoren van de latente constructen, waarbij elk item slechts laadde op het beoogde construct. In het theoretische structurele model werden de volgende relaties verondersteld: een positieve relatie tussen heden- en toekomstfocus en intentie om door te werken, tussen heden- en toekomstfocus en leertoenadering, en tussen leertoenadering en intentie om door te werken; een negatieve relatie tussen verledenfocus en intentie om door te werken; een positieve relatie tussen verledenfocus en leervermijding; en een negatieve relatie tussen leervermijding en intentie om door te werken. Ook werd een verband verondersteld van de controlevariabelen (gezondheid, leeftijd, geslacht, financiële situatie, en organisatie) 
met de intentie om te blijven werken. De covarianties tussen heden-, verleden- en toekomstfocus en tussen leertoenaderings- en leervermijdingsdoelen werden vrij geschat. Ook de error-covariantie tussen leertoenaderings- en leervermijdingsdoelen werd vrij geschat (Preacher \& Hayes, 2008). De errorvarianties van de 1-itemmetingen (leeftijd, geslacht, financiële situatie, en organisatie) werd gefixeerd op 0 .

Om te beoordelen hoe goed de modellen aansloten bij de data gebruikten we de volgende absolute fitmaten: (1) de Chi-square Goodness-of-Fit test ( $\chi^{2}$-test), (2) de Standardized Root Mean Square Residual (SRMR), en (3) de Root Mean Square Error of Approximation (RMSEA). Omdat deze fitmaten afhankelijk zijn van de steekproefgrootte, rapporteren we, in navolging van Marsh, Balla en Hau (1996), tevens de volgende incrementele fitmaten: (4) de Non-Normed Fit Index (NNFI), en (5) de Comparative Fit Index (CFI). RMSEA-waarden van .06 of kleiner en SRMR-waarden van .08 of kleiner duiden op een aanvaardbare fit met de data (Hu \& Bentler, 1999). Voor de incrementele fitmaten geldt dat waarden van .95 of groter in het algemeen duiden op een goede beschrijving van de data; waarden kleiner dan .90 duiden erop dat het model opnieuw moet worden gespecifieerd (Bentler \& Bonett, 1980; Hu \& Bentler, 1999). De $\chi^{2}$-test is gebruikt om de geneste modellen te vergelijken.

\section{Resultaten}

\subsection{Beschrijvende statistieken}

In tabel 1 zijn de gemiddelden, standaarddeviaties en correlaties voor alle variabelen weergegeven. Uit tabel 1 blijkt dat de intentie om door te werken tot aan het pensioen positief samenhangt met leertoenaderingsdoelen en negatief met leervermijdingsdoelen. Conform onze verwachtingen bestaat er een positief verband tussen verledenfocus en leervermijdingsdoelen en hangen een heden- en toekomstfocus positief samen met leertoenaderingsdoelen. De drie temporele focusschalen hangen geen van alle significant samen met de intentie om tot het pensioen door te werken.

\subsection{Test van het meetmodel}

De resultaten van de covariantie-structuuranalyses worden gepresenteerd in tabel 2. Uit de tabel wordt duidelijk dat de fit van het theoretische meetmodel (Model 1) aanvaardbaar is. Model 1 werd vervolgens vergeleken met een model waarbij alle items op één factor laden (Model 2); een model waarbij alle temporele focusitems op één factor laden (Model 3); en een model waarbij leertoenaderingsen leervermijdingsdoelen op één factor laden (Model 4). Zoals blijkt uit tabel 2, is de fit van het theoretisch meetmodel beter dan dat van de alternatieve meetmodellen. Het theoretisch meetmodel wordt daarom gebruikt als basis voor de verdere analyses (Anderson \& Gerbing, 1988). 
Tabel 1 Gemiddelden, standaarddeviaties, Cronbach alpha's en correlaties van en tussen de onderzoeksvariabelen $(N=548)$

\begin{tabular}{|c|c|c|c|c|c|c|c|c|c|c|c|c|}
\hline Schaal & $M$ & $S D$ & I & 2 & 3 & 4 & 5 & 6 & 7 & 8 & 9 & 10 \\
\hline I. Leeftijd & 53.26 & .16 & - & & & & & & & & & \\
\hline 2. Verledenfocus & 2.96 & .69 & $.13 * *$ & $(.75)$ & & & & & & & & \\
\hline 3. Hedenfocus & 3.94 & .68 & .01 & $.21^{* *}$ & $(.56)$ & & & & & & & \\
\hline $\begin{array}{l}\text { 4. Toekomstfo- } \\
\text { cus }\end{array}$ & 3.64 & .77 & $-.11 * *$ & $.31 * *$ & $.59 *$ & $(.76)$ & & & & & & \\
\hline $\begin{array}{l}\text { 5. Leervermij- } \\
\text { dingsdoelen }\end{array}$ & 2.52 & .98 & $-.10 *$ & $.16 * *$ & -.04 & .04 & $(.8 \mathrm{I})$ & & & & & \\
\hline $\begin{array}{l}\text { 6. Leertoenade- } \\
\text { ringsdoelen }\end{array}$ & 4.40 & .61 & -.07 & .04 & $.17^{*}$ & $.19 * *$ & .02 & $(.75)$ & & & & \\
\hline $\begin{array}{l}\text { 7. Intentie door- } \\
\text { werken }\end{array}$ & 3.70 & 1.10 & $.12 * *$ & .01 & .06 & .07 & $-.13 * *$ & $.20 * *$ & $=(.94)$ & & & \\
\hline 8. Gezondheid & 3.83 & .84 & -.05 & -.06 & .05 & .04 & $-.19 * *$ & $.12 * *$ & $.14 * *$ & $=(.89)$ & & \\
\hline $\begin{array}{l}\text { 9. Financiële situ- } \\
\text { atie }\end{array}$ & 3.59 & 1.86 & $.12 * *$ & .03 & .02 & -.06 & $-.10^{*}$ & -.05 & $-.15^{* *}$ & .05 & - & \\
\hline $\begin{array}{l}\text { 10. Organisatie } \\
\text { (univ. vs. verz.) }\end{array}$ & - & - & $-.22 * *$ & .01 & -.01 & .08 & -.01 & .06 & $-.27 * *$ & -.02 & -.02 & - \\
\hline II. Geslacht $†$ & - & - & $-.14 * *$ & -.03 & .03 & .02 & -.01 & $.12 * *$ & $-.10^{*}$ & $.09 *$ & -.05 & $-.13 * *$ \\
\hline
\end{tabular}

† Geslacht: 0 = man, I = vrouw

$* p<.05$ (tweezijdig); ** $p<.01$ (tweezijdig)

\subsection{Test van het structurele model}

Eerst onderzochten we de directe relaties tussen leerdoelen en intentie om door te werken tot aan het pensioen (Model 5). De fit van dit model is acceptabel, $\chi^{2}(273)=1005.32 ;$ RMSEA $=.07 ;$ SRMR $=.06 ;$ CFI $=.91 ;$ NNFI $=.89$. Zoals verwacht blijkt er een positief verband tussen leertoenaderingsdoelen en intentie om door te werken $(\gamma=.32, p<.01)$ en een negatief verband tussen leervermijdingsdoelen en intentie om door te werken $(\gamma=-.17, p<.01)$. Hiermee vinden we ondersteuning voor de hypotheses $3 \mathrm{a}$ en $3 \mathrm{~b}$. Vervolgens toetsten we het directeeffectenmodel (Model 6), dat rechtstreekse verbanden veronderstelt tussen temporele focus en intentie om door te werken. De fit van dit model is acceptabel, $\chi^{2}(272)=1080.80 ;$ RMSEA $=.074 ;$ SRMR $=.07$; CFI $=.91$; NNI $=.88$. Zoals verwacht blijkt er een positief verband tussen toekomstfocus en intentie om door te werken $(\gamma=.33, p<.01)$. In tegenstelling tot de verwachtingen hangt de hedenfocus negatief samen met de intentie om door te werken $(\gamma=-.19, p<.05)$. Het verband tussen verledenfocus en intentie om door te werken blijkt niet significant $(\gamma=-.05, n s)$.

In een volgende stap toetsten we een volledig gemedieerd model (Model 7, figuur 1). In dit model worden de volgende relaties verondersteld: verledenfocus -> leervermijding -> intentie doorwerken; hedenfocus -> leertoenadering -> intentie doorwerken; toekomstfocus $->$ leertoenadering $\rightarrow>$ intentie doorwerken. De fit van dit model was acceptabel, $\chi^{2}(286)=1069.85$; RMSEA = .071; SRMR = .07; $\mathrm{CFI}=.91 ; \mathrm{NNFI}=.89$. 
Tabel 2 Fit-indices en $\chi^{2}$-verschiltoetsen van diverse geneste modellen in een covariantie-structuuranalyse $(N=548)$

\begin{tabular}{|c|c|c|c|c|c|c|c|c|c|}
\hline Model & $\chi^{2}$ & $d f$ & RMSEA & SRMR & CFI & NNFI & $\begin{array}{l}\text { Model- } \\
\text { vergelij- } \\
\text { kingen }\end{array}$ & $\Delta \chi^{2}$ & $\Delta d f$ \\
\hline $\begin{array}{l}\text { I Theoretisch meet- } \\
\text { model (MI) }\end{array}$ & $625.91 * *$ & 205 & .061 & .06 & .95 & .94 & & & \\
\hline $\begin{array}{l}2 \text { Meetmodel met alle } \\
\text { items op één } \\
\text { gemeenschappelijke } \\
\text { factor (M2) }\end{array}$ & $6688.23 * *$ & 230 & .227 & .20 & .38 & .32 & M2-MI & $6062.32 * *$ & 25 \\
\hline $\begin{array}{l}3 \text { Meetmodel met } \\
\text { temporele focus- } \\
\text { items op één factor } \\
\text { (M3) }\end{array}$ & $1270.75 * *$ & 220 & .093 & .08 & .89 & .87 & M3-MI & $644.84 * *$ & 15 \\
\hline $\begin{array}{l}4 \text { Meetmodel met } \\
\text { leertoenaderings- } \\
\text { en leervermijdings- } \\
\text { doelen items op } \\
\text { één factor (M4) }\end{array}$ & $1919.17^{* *}$ & 216 & .120 & .12 & .84 & .81 & M4-MI & 1293.26 ** & II \\
\hline $\begin{array}{l}5 \text { Structureel model } \\
\text { met directe relaties } \\
\text { tussen leerdoelen } \\
\text { en intentie om } \\
\text { door te werken } \\
\text { (M5) }\end{array}$ & $1005.32 * *$ & 273 & .070 & .06 & .91 & .89 & & & \\
\hline $\begin{array}{l}6 \text { Structureel model } \\
\text { met directe relaties } \\
\text { tussen temporele } \\
\text { focus en intentie } \\
\text { om door te werken } \\
\text { (M6) }\end{array}$ & $1080.80 * *$ & 272 & .074 & .07 & .91 & .88 & & & \\
\hline $\begin{array}{l}7 \text { Volledig gemedi- } \\
\text { eerd structureel } \\
\text { model (M7) }\end{array}$ & $1069.85 * *$ & 286 & .071 & .07 & .91 & .89 & & & \\
\hline $\begin{array}{l}8 \text { Partieel gemedieerd } \\
\text { structureel model } \\
\text { (M8) }\end{array}$ & $1069.13^{* *}$ & 283 & I.07I & .07 & .91 & .89 & M7-M8 & 0.72 & 3 \\
\hline
\end{tabular}

Vervolgens toetsten we een partieel gemedieerd model (Model 8) door aan Model 7 de directe paden tussen temporele focus en intentie om door te werken toe te voegen. De fit van dit model was opnieuw acceptabel, $\chi^{2}(283)=1069.13$; RMSEA $=.071 ;$ SRMR $=.07 ; \mathrm{CFI}=.91 ; \mathrm{NNFI}=.89$. De fit van dit model is echter niet significant beter dan de fit van Model 7, $\Delta \chi^{2}(3)=0.72$, $n s$, en geen van de directe paden blijkt significant.

Tot slot voerden we Sobel-tests uit (Sobel, 1982) om na te gaan of het effect van verleden- en toekomstfocus gedragen wordt door respectievelijk leervermijdingsen leertoenaderingsdoelen. De Sobel-test bevestigt het indirecte effect van verledenfocus naar intentie om door te werken via leervermijdingsdoelen $(z=-3.63$, 
$p<.01$ ), en van toekomstfocus naar intentie om door te werken via leertoenaderingsdoelen $(z=5.09, p<.01)$.

Samengevat vinden we dat toekomstfocus positief en verledenfocus negatief samenhangt met intentie om door te werken (hypothese $1 \mathrm{a}$ en $1 \mathrm{c}$ bevestigd). Er is een positief verband tussen toekomstfocus en leertoenaderingsdoelen en tussen verledenfocus en leervermijdingsdoelen (hypothese $2 a$ en $2 c$ bevestigd). Leertoenaderingsdoelen zijn positief en leervermijdingsdoelen zijn negatief gerelateerd met de intentie om door te werken (hypothese $3 \mathrm{a}$ en $3 \mathrm{~b}$ bevestigd). Leertoenaderingsdoelen mediëren de relatie tussen toekomstfocus en de intentie om door te werken, terwijl leervermijdingsdoelen de relatie mediëren tussen verledenfocus en intentie om door te werken (hypothese $4 \mathrm{a}$ en $4 \mathrm{c}$ bevestigd). Uit figuur $1 \mathrm{blijkt}$ verder dat er een sterkere intentie bestaat om door te werken tot aan het pensioen bij vrouwen, universiteitsmedewerkers en medewerkers die aangeven gezond te zijn en er financieel ongunstig voor te staan.

\section{Discussie}

\subsection{Reflectie op de uitkomsten}

Het doel van deze studie was om te onderzoeken wat de groeiende groep oudere werknemers motiveert om te blijven werken. Het uitgangspunt hierbij was dat de werkgerelateerde temporele focus van oudere werknemers, dat wil zeggen hun gerichtheid op het professionele verleden, heden of de toekomst, samenhangt met leertoenaderings- dan wel leervermijdingsdoelen, die op hun beurt weer verband houden met de pensioenintenties.

De resultaten van onze studie hebben enkele interessante inzichten opgeleverd. Op de eerste plaats bleek dat een focus op de toekomst inderdaad positief samenhangt met het stellen van leertoenaderingsdoelen. Dit betekent dat naarmate werknemers meer geneigd zijn zich in hun werk en carrière vooral te richten op de toekomst, ze ook een sterkere drive hebben om te leren en zich te blijven ontwikkelen. Het stellen van dergelijke leertoenaderingsdoelen hing vervolgens weer positief samen met de intentie om door te werken tot aan de pensioengerechtigde leeftijd. Kennelijk zijn mensen meer gemotiveerd om langer te blijven werken als ze ook in staat zijn om zo veel mogelijk te blijven leren op het werk en zichzelf te blijven ontwikkelen in hun baan. Deze bevinding is in overeenstemming met een conclusie uit de studie van Bal, De Lange, Ybema, Jansen en Van der Velde (2011), die luidde dat indien oudere werknemers worden gestimuleerd om zich te blijven ontwikkelen, ze ook meer gemotiveerd zijn om langer door te werken. In dezelfde lijn toonde een studie van Van Vuuren, Caniels en Semeijn (2011) het belang aan van een zogenoemd 'leven lang leren'. Zij vonden een positief verband tussen een leven lang leren en employability, werkvermogen en vitaliteit; alle drie belangrijke pijlers van duurzame inzetbaarheid. Eerder onderzoek van De Graaf en collega's (2011) liet ook al zien dat zowel de leerwaarde van de functie zelf als de mogelijkheid tot training en opleiding samenhingen met employability, hetgeen weer een positieve uitwerking had op de intentie om langer door te werken. 


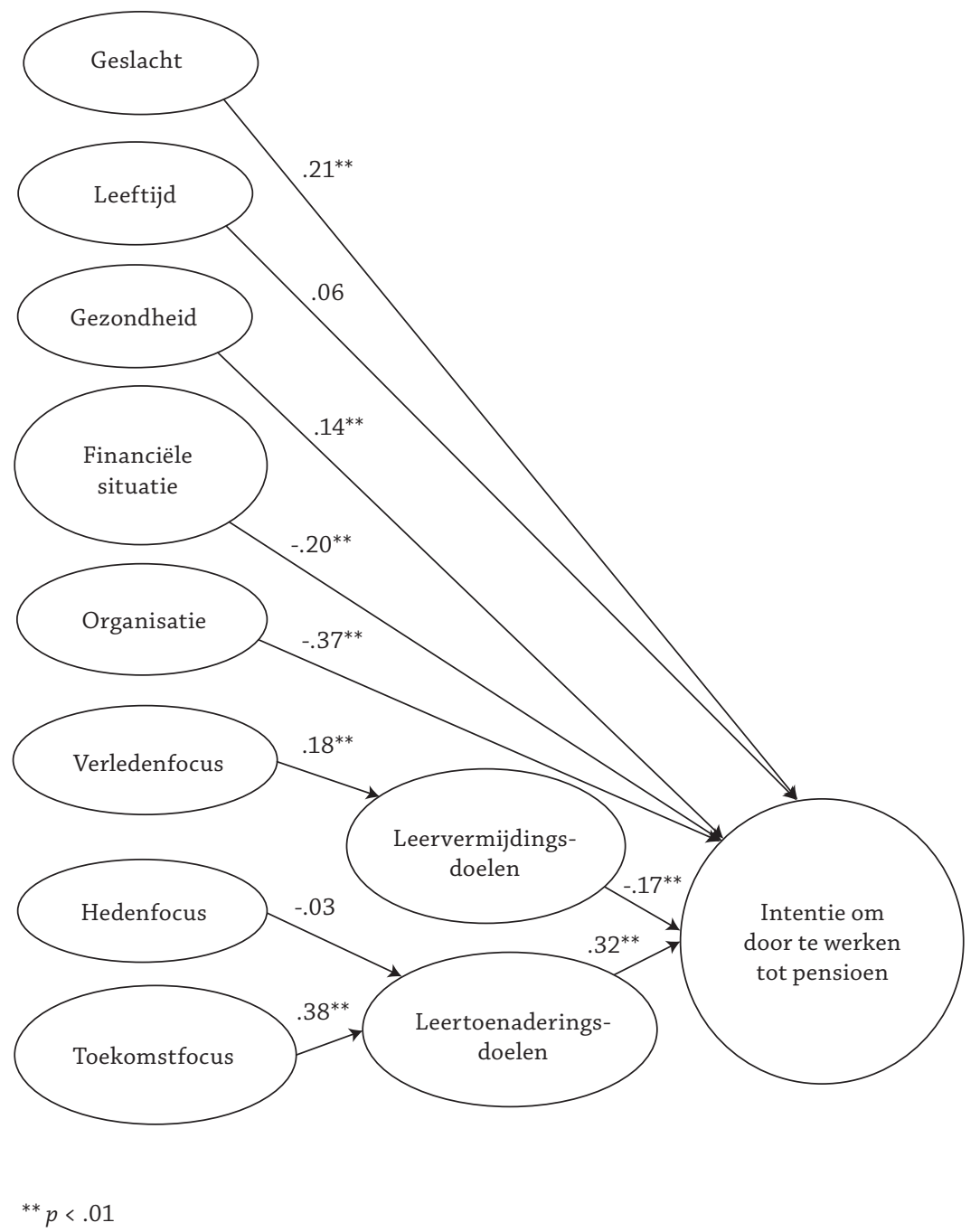
Figuur $1 \quad \begin{aligned} & \text { Gestandaardiseerde coëfficiënten van het volledig gemedieerd } \\ & \text { structureel model (M7) }\end{aligned}$

Het lijkt er dus op dat een leeroriëntatie van - in dit geval - oudere werknemers van belang is voor issues als motivatie, duurzame inzetbaarheid en intentie om door te werken tot aan het pensioen. Hierbij is echter wel van groot belang dat de organisatie en/of het werk zelf mensen ook in staat stelt om zich te blijven ontwikkelen en te blijven leren. Immers, we weten uit onderzoek op basis van de 'person-environment' fit gedachtegang (Edwars \& Shipp, 2007) dat indien er geen sprake is van een zogenoemde 'needs-supply fit', d.w.z. de mate van overeenstemming tussen de voorzieningen die de omgeving biedt (in dit geval leer- en ontwikkelingsmogelijkheden) en de persoonlijke behoeften van de werknemer (in dit 
geval een leertoenaderingsdoeloriëntatie), werknemers een misfit zullen ervaren die ertoe zal leiden dat men juist minder gemotiveerd is om door te werken. De huidige studie voegt aan bovenstaand inzicht over de motiverende rol van leren toe, dat een dergelijke leeroriëntatie gestimuleerd kan worden door het hebben van een focus op de toekomst.

Uit deze studie leren we ook dat we oudere werknemers kunnen stimuleren langer door te werken door hun blijvend ontwikkelingskansen te bieden. Toch worden oudere werknemers vaak gestereotypeerd als 'niet geïnteresseerd om bij te leren' of 'niet geïnteresseerd om deel te nemen aan trainingsprogramma's' (Maurer, Wrenn \& Weiss, 2003). Deze denkbeelden zijn wijdverspreid op de werkvloer, ook onder managers (Henkens, 2005). Het gevaar is reëel dat deze stereotypes, en de managementgedragingen die eruit voortspruiten (bijv. oudere werknemers leermogelijkheden ontzeggen), oudere werknemers ontmoedigen om naar hun professionele toekomst te kijken. Ze krijgen immers, direct en indirect, het signaal dat er nog weinig van hen verwacht wordt. Dit voorbeeld over de rol van temporele focus in de relatie tussen stereotypering en pensioenintentie illustreert waarom het construct temporele focus volgens ons een meer prominente plaats verdient in theorievorming over de werkmotivatie van ouderen.

Tegen de verwachting in bleek uit de structuuranalyses dat een hedenfocus niet samenhing met het stellen van leertoenaderingsdoelen en ook niet met de intentie om door te werken tot aan het pensioen. We denken dat hier een inhoudelijke en/of methodologische verklaring voor gegeven kan worden. Inhoudelijk gezien kan het zijn dat werknemers die voornamelijk gericht zijn op het heden, nog niet zo bezig zijn met nadenken over hun pensionering. Ze zijn gericht op het hier en nu en op wat er nu in hun professionele leven aan het gebeuren is. Pensionering is per definitie iets wat denken over de toekomst vereist, en dat stellen ze liever nog uit. Uit de structuuranalyse bleek verder dat de relatie tussen hedenfocus en leertoenaderingsdoelen niet significant was. Dit zou een gevolg kunnen zijn van de redelijk hoge intercorrelatie tussen heden- en toekomstfocus $(r=.59)$. De bivariate correlatie tussen hedenfocus en leertoenaderingsdoelen is immers wél significant $(r=.17)$. Vooralsnog is dus uit de resultaten van deze studie niet geheel duidelijk wat precies de rol is van een hedenfocus als het gaat om de motivatie om door te werken tot aan het pensioen. Gezien het feit dat uit eerdere studies van Shipp en collega's bleek (2009) dat een hedenfocus wel significant samenhing met werktevredenheid en organisatiebetrokkenheid, is het nog té vroeg om het motiverende potentieel van een hedenfocus te verwerpen. Hiervoor hebben we meer empirische studies nodig die expliciet ingaan op de rol van een hedenfocus bij besluitvorming over al dan niet doorwerken tot het pensioen. Toekomstig onderzoek zou bijvoorbeeld op zoek kunnen gaan naar moderatoren in de relatie tussen hedenfocus en pensioenintentie. Zo is het mogelijk dat de relatie tussen hedenfocus en pensioenintentie afhankelijk is van hoe positief de huidige werksituatie wordt ingeschat.

Tot slot bleek uit onze studie dat een focus op het verleden positief samenhing met het piekeren over hun beperkte leerpotentieel (leervermijdingsdoelen). Dit betekent dat naarmate werknemers meer de neiging hebben om vooral te denken aan hun vroegere dagen als werknemer en aan gebeurtenissen uit hun professio- 
Doeloriëntaties en het tijdsperspectief van oudere werknemers: is er een verband met pensioenintenties?

nele verleden, ze zich ook meer zorgen maken over hun leergedrag op het werk. Ze zijn bezorgd dat ze te weinig uit hun werk halen en dat ze onvoldoende leren. Blijkbaar brengt een focus op het professionele verleden toch vooral negatieve gedachten naar boven. Voorbeelden kunnen zijn piekeren over fouten, onvrede met de huidige situatie in vergelijking met die van vroeger en spijt over bepaalde beslissingen (Shipp et al., 2009). Het hebben van een dergelijke leervermijdingsoriëntatie hing vervolgens weer negatief samen met de intentie om door te werken tot aan de pensioengerechtigde leeftijd. Oudere werknemers met een werkgerelateerde verledenfocus beschouwen tijd als een schaars goed en zien voor zichzelf heel wat minder leermogelijkheden in hun werk in het verschiet. Het is plausibel te veronderstellen dat deze werknemers minder willen investeren in hun professionele loopbaan en meer in hun familiaire relaties (Schreurs, Van den Broeck, Notelaers, Van der Heijden \& De Witte, 2012).

Verder werd gevonden dat gezondheid positief en financiële situatie negatief samenhing met de intentie om door te werken tot aan het pensioen. Globaal gezien zullen werknemers met een slechte gezondheid en hoge financiële zekerheid sneller met pensioen gaan dan werknemers met een goede gezondheid of lagere financiële zekerheid (Schalk et al., 2010; De Graaf et al., 2011). Tot slot bleken werknemers van de universiteit een hogere intentie te hebben om door te werken tot de pensioengerechtigde leeftijd. Dit kan mogelijk verklaard worden doordat de steekproef van de universiteit gemiddeld hoger opgeleid was. Het zou kunnen dat hoger opgeleiden meer op de toekomst gefocust zijn, doordat zij gemiddeld meer carrièrekansen en doorgroeimogelijkheden hebben, en daardoor een hogere intentie hebben om door te werken tot de pensioengerechtigde leeftijd.

\subsection{Beperkingen en aanwijzingen voor vervolgonderzoek}

Deze studie heeft een aantal beperkingen. Allereerst betreft het een cross-sectionele studie waardoor er geen uitspraken gedaan kunnen worden over de causaliteit van de gevonden verbanden. Dit is een belangrijke beperking in een onderzoek naar een aan tijd gerelateerd onderwerp zoals het ouder worden van werknemers (Schalk et al., 2010), temeer omdat veel van de relaties in deze studie nog niet eerder zijn onderzocht (zie voor een uitzondering Zacher \& De Lange, 2011). Zo is het bijvoorbeeld belangrijk om meer inzicht te krijgen in de temporele relatie tussen hedenfocus en het hanteren van leertoenaderingsdoelen: iets wat niet duidelijk is geworden uit de huidige studie.

In het huidige onderzoek is niet ingegaan op eventuele temporele focusprofielen. Er is slechts gekeken naar de afzonderlijke dimensies van temporele focus. Er werden echter wel significante positieve correlaties gevonden tussen de schalen onderling. Vervolgonderzoek zou daarom verder kunnen ingaan op mogelijke interactie-effecten van de verschillende temporele foci.

De betrouwbaarheid van de hedenfocus is laag, en de schaal bestaat slechts uit twee items. Het is dus van belang om in nieuw onderzoek een aantal aanvullende items te ontwikkelen. Hoogstwaarschijnlijk zal dit ook ten goede komen aan de betrouwbaarheid van de schaal. 
In dit onderzoek is een ondergrens van 45 jaar gehanteerd om vast te stellen of een werknemer 'oud' is. Onderzoek laat echter zien dat kalenderleeftijd een beperkt construct is om vast te stellen of een werknemer oud is of niet (Carstensen, 2006; Logan, Ward \& Spitze, 1992; Kooij, De Lange, Jansen \& Dikkers, 2008). Vervolgonderzoek zou daarom aanvullende criteria kunnen hanteren voor het vaststellen van een 'oudere' werknemer (zie Kooij et al., 2008 voor meer informatie over de operationalisatie van leeftijd).

Temporele foci en de doeloriëntaties toonden slechts bescheiden correlaties met de intentie om door te werken tot aan de pensioenleeftijd. Dit zou te maken kunnen hebben met 'restriction of range' omwille van de relatief hoogopgeleide steekproef. Vervolgonderzoek met een heterogene steekproef qua opleiding lijkt ons daarom aangewezen. Ook kan het de moeite lonen om de voorspellende waarde van temporele foci en de doeloriëntaties te vergelijken met die van reeds gevestigde predictoren van pensioenintentie zoals attitudes ten aanzien van pensionering, persoonlijkheid, financiële situatie en gezondheid (Wang \& Schultz, 2010).

Tot slot een opmerking over de operationalisatie van leertoenaderings- en leervermijdingsdoelen. De vragen behorende bij leertoenadering beginnen steeds met 'ik wil' en 'ik vind het belangrijk'. Bij leervermijding gaat het steeds om 'ik ben bang' en 'ik maak me zorgen'. Puur door de formulering van deze items zal de kans groot zijn dat leertoenadering een indicator is van een positieve uitkomst (bijv. doelgerichtheid, veerkracht en positieve emoties), terwijl leervermijding een indicator zal zijn van een negatieve uitkomst (bijv. negatief affect, angst, neuroticisme). Mogelijk heeft deze affectieve toon een belangrijker invloed op de samenhang met andere variabelen dan de inhoudelijk leerdoelen. In toekomstig onderzoek zou daarom kunnen worden geprobeerd om de items zodanig te formuleren dat dit geen rol (meer) speelt.

\subsection{Conclusie}

$\mathrm{Al}$ met al wijzen onze bevindingen op het belang van het blijvend motiveren van oudere werknemers door middel van uitdagende taken en leermogelijkheden. Een werkgerelateerde focus op de toekomst hangt positief samen met de intentie om door te werken tot het pensioen. Deze relatie kan worden verklaard door leertoenaderingsdoelen. Een werkgerelateerde focus op het verleden blijkt via leervermijdingsdoelen een indirect negatief verband te hebben met pensioenintentie. Om ervoor te zorgen dat ouderen langer aan het werk blijven, moeten managers werknemers dus stimuleren om te (blijven) focussen op de toekomst en op het stellen van leertoenaderingsdoelen (Elliot, 2005). 


\section{Praktijkbox}

Wat betekenen de resultaten voor de praktijk?

- Managers zouden een toekomstfocus voor oudere werknemers moeten faciliteren door meer op de verdere toekomst gerichte omschrijvingen te gebruiken van taakgerelateerde doelen (bijvoorbeeld: volgend jaar is deze cursus afgemaakt en zijn deze nieuwe vaardigheden aangeleerd) (De Lange al., 2010). Het is daarbij belangrijk dat werknemers de kans krijgen om tijd en energie te steken in het aanleren van nieuwe vaardigheden om zich verder en breder te ontwikkelen in plaats van te focussen op routineprestaties.

- Een belangrijke taak voor managers is om een focus op leertoenaderingsdoelen te faciliteren voor oudere werknemers (Elliot, 2005). Dit kan door te evalueren in termen van vooruitgang, verbetering en door vergissingen te accepteren als onderdeel van het leerproces (Ames, 1992).

- De arbeidsmotivatie van oudere werknemers kan worden gestimuleerd als de baan verrijkend is en als er sprake is van een constructieve leertoenadering en een toekomstgerichte managementstijl (De Lange, Taris et al., 2010).

\section{Literatuur}

Adams, G.A. \& Beehr, T.A. (1998). Turnover and retirement: A comparison of their similarities and differences. Personnel Psychology, 51, 643-655.

Aguinis, H. \& Kraiger, K. (2009). Benefits of training and development for individuals and teams, organizations, and society. Annual Review of Psychology, 60, 451-474.

Ames, C. (1992). Achievement goals, motivational climate and motivational processes. In G.C. Roberts (Ed.), Motivation in sport and exercise (pp. 161-176). Champaign, IL: Human Kinetics Books.

Anderson, J.C. \& Gerbing, D.W. (1988). Structural equation modeling in practice: A review and recommended two-step approach. Psychological Bulletin, 103, 411-423.

Bal, P.M., De Lange, A.H., Ybema, J.F., Jansen, P.G.W. \& Van der Velde, M.E.G. (2011). Age and trust as moderators in the relation between procedural justice and turnover: A large-scale longitudinal study. Applied Psychology, An International Review, 60, 66-86.

Baranik, L.E., Stanley, L.J., Bynum, B.H. \& Lance, C.E. (2010). Examining the construct validity of mastery-avoidance achievement goals: A meta-analysis. Human Performance, 23, 265-282.

Beehr, T.A. (1986). The process of retirement: A review and recommendation for future investigation. Personnel Psychology, 39, 31-55.

Bentler, P.M. \& Bonett, D.G. (1980). Significance tests and goodness of fit in the analysis of covariance structures. Psychological Bulletin, 88, 588-606.

Bluedorn, A.C. (2002). The human organization of time: Temporal realities and experience. Stanford, CA: Stanford Business Books.

Boumans, N.P.G., De Jong, A.H.J. \& Van der Linden, L. (2008). Determinants of early retirement intentions among Belgian nurses. Journal of Advanced Nursing, 63, 64-74. 
Carstensen, L.L. (2006). The influence of a sense of time on human development. Science, 312, 1913-1915.

Carstensen, L.L., Isaacowitz, D.M. \& Charles, S.T. (1999). Taking time seriously: A theory of socioemotional selectivity. American Psychologist, 54, 165-181.

CBS. (2012). Pensioenleeftijd werknemers ruim 63 jaar. Verkregen op 26 maart 2012 van www.cbs.nl/nl-NL/menu/themas/gezondheid-welzijn/publicaties/artikelen/archief/ 2012/2012-3557-wm.htm

De Graaf, S., Peeters, M.C.W. \& Van der Heijden, B. (2011). De relatie tussen employability en de intentie tot langer doorwerken. Gedrag \& Organisatie, 24, 374-391.

De Lange A.H., Van der Heijden, B.I.J.M. \& Peeters, M.C.W. (2013). Een leven lang inzetbaar? Duurzame inzetbaarheid op het werk: interventies, best practices, en integrale benaderingen. Alphen aan den Rijn: Vakmedianet.

De Lange, A.H., Van Yperen, N.W., Van der Heijden, B.I.J.M. \& Bal, M. (2010). Dominant achievement goals of older workers and their relationship with motivation related outcomes. Journal of Vocational Behaviour, 77, 118-125.

De Lange A.H., Ybema, J.F. \& Schalk, R. (2011). Stoppen of doorgaan? Theorie en praktijk van pensionering en langer doorwerken. Gedrag \& Organisatie, 24, 323-341.

Edwars, J.R. \& Shipp, A.J. (2007). The relationship between person-environment fit and outcomes: An integrative theoretical framework. In C. Ostroff \& T. A. Judge (Eds.), Perspectives on organizational fit (pp. 209-258). San Francisco: Jossey-Bass.

Elliot, A.J. (2005). A conceptual history of the achievement goal construct. In A.J. Elliot \& C.S. Dweck (Eds.), Handbook of competence and motivation (pp. 52-72). New York: The Guilford Press.

Elliot, A.J. \& Church, M. (1997). A hierarchical model of approach and avoidance achievement motivation. Journal of Personality and Social Psychology, 72, 218-232.

Elliot, A.J. \& McGregor, H.A. (2001). A 2 x 2 achievement goal framework. Journal of Personality and Social Psychology, 80, 501-519.

Elliot, A.J. \& Thrash, T.M. (2001). Achievement goals and the hierarchical model of achievement motivation. Educational Psychology Review, 13, 139-156.

Frins, W., Van Ruysseveldt, J. \& Syroit, J. (2011). Doorwerken tot aan het pensioen? Samenhang tussen werkkenmerken en het ingeschatte doorwerkvermogen. Gedrag \& Organisatie, 24, 392-409.

Henkens, K. (2005). Stereotyping older workers and retirement: The managers' point of view. Canadian Journal on Aging, 24, 353-366.

Hu, L. \& Bentler, P.M. (1999). Cutoff criteria for fit indexes in covariance structure analysis: Conventional criteria versus new alternatives. Structural Equation Modeling, 6, 1-55.

Kanfer, R. \& Ackerman, P.L. (2000). Individual differences in work motivation: Further explorations of a trait framework. Applied Psychology: An International Review, 49, 470-482.

Karniol, R. \& Ross, M. (1996). The motivational impact of temporal focus: Thinking about the future and the past. Annual Review of Psychology, 47, 593-620.

Kooij, D., De Lange, A.H., Jansen, P. \& Dikkers, J. (2008). Older workers' motivation to continue to work: Five meanings of age. Managerial Psychology, 23, 364-394.

Koppes, L.L.J., De Vroome, E.M.M., Mol, M.E.M., Janssen, B.J.M. \& Van den Bossche, S.N.J. (2011). Nationale Enquête Arbeidsomstandigheden 2010: Methodologie en globale resultaten. Hoofddorp: TNO.

Lee, J.Q., McInerney, D.M., Liem, G.A.D. \& Ortiga, Y.P. (2010). The relationship between future goals and achievement goal orientations: An intrinsic-extrinsic motivation perspective. Contemporary Educational Psychology, 35, 264-279. 
Doeloriëntaties en het tijdsperspectief van oudere werknemers: is er een verband met pensioenintenties?

Logan, J.R., Ward, R. \& Spitze, G. (1992). As old as you feel: Age identity in middle and later life. Social Forces, 71, 451-467.

Maehr, M.L. \& Kleiber, D.A. (1981). The graying of achievement motivation. American Psychologist, 36, 787-793.

Marsh, H.W., Balla, J.R. \& Hau, K.T. (1996). An evaluation of incremental fit indices: A clarification of mathematical and empirical properties. In G.A. Marcoulides \& R.E. Schumacker (Eds.), Advanced structural equation modeling: Issues and techniques (pp. 315-353). Mahwah, NJ: Erlbaum.

Maurer, T.J., Wrenn, K.A. \& Weiss, E.M. (2003). Toward understanding and managing stereotypical beliefs about older workers' ability and desire for learning and development. Research in Personnel and Human Resources Management, 22, 253-285.

Meece, J.L., Glienke, B.B. \& Burg, S. (2006). Gender and motivation. Journal of School Psychology, 44, 351-373.

Preacher, K.J. \& Hayes, A.F. (2008). Asymptotic and resampling strategies for assessing and comparing indirect effects in multiple mediator models. Behavior Research Methods, 40, 879-891.

Rijksoverheid. (2011). Kabinet en sociale partners eens over uitwerking pensioenakkoord. Gedownload op 5 september 2011 van www.rijksoverheid.nl/documenten-en-publica ties/persberichten/2011/06/10/kabinet-en-sociale-partners-eens-over-uitwerkingpensioenakkoord.html

Schalk, R., Van Veldhoven, M., De Lange, A.H., De Witte, H., Kraus, K., Stamov-Rossnagel, C. \& Zacher, H. (2010). Moving European research on work and ageing forward: Overview and agenda. European Journal of Work and Organizational Psychology, 19, 76-101.

Schreurs, B., Van den Broeck, A, Notelaers, G., Van der Heijden, B. \& De Witte, H. (2012). De relatie tussen werkeisen, energiebronnen, spanning en werkplezier: een kwestie van leeftijd? Gedrag \& Organisatie, 25, 5-27.

Shipp, A.J., Edwards, J.R. \& Lambert, L.S. (2009). Conceptualization and measurement of temporal focus: The subjective experience of the past, present and future. Organizational Behavior and Human Decision Processes, 110, 1-22.

Sideridis, G.D. (2008). The regulation of affect, anxiety, and stressful arousal from adopting mastery-avoidance goal orientations. Stress and Health, 24, 55-69.

Simons, J., Vansteenkiste, M., Lens, W. \& Lacante, M. (2004). Placing motivation and future time perspective theory in a temporal perspective. Educational Psychology Review, 16, 121-139.

Sobel, M.E. (1982). Asymptotic intervals for indirect effects in structural equations models. In S. Leinhart (Ed.), Sociological methodology (pp. 290-312). San Francisco: Jossey-Bass.

Talaga, J.A. \& Beehr, T.A. (1989). Retirement: a psychological perspective. International Review of Industrial and Organizational Psychology, 4, 185-211.

Talaga, J.A. \& Beehr, T.A. (1995). Are there gender differences in predicting retirement decisions? Journal of Applied Psychology, 80, 16-28.

Van Dam, K., Van der Vorst, J.D.M. \& Van der Heijden, B.I.J.M. (2009). Employees' intentions to retire early: A case of planned behavior and anticipated work conditions. Journal of Career Development, 35, 265-289.

Van Vuuren, T., Caniëls, M.C.J. \& Semeijn, J.H. (2011). Duurzame inzetbaarheid en een leven lang leren. Gedrag \& Organisatie, 24, 357-374.

Wang, M. \& Shultz, K.S. (2010). Employee retirement: A review and recommendations for future investigation. Journal of Management, 36, 172-206. 
Zacher, H. \& De Lange, A.H. (2011). Relations between chronic regulatory focus and future time perspective: Results of a cross-lagged structural equation model. Personality and Individual Differences, 50, 1255-1260.

Zappala, S., Depolo, M., Fraccaroli, F., Guglielmi, D. \& Sarchielli, G. (2008). Postponing job retirement? Psychosocial influences on the preference for early or late retirement. Career Development International, 13,150-167.

\section{Bijlage A: Vragenlijst}

\section{Temporele focus}

Antwoordcategorieën: 1 = nooit, 2 = zelden, 3 = soms, 4 = regelmatig, 5 = vaak

\section{Verleden:}

1. Ik herbeleef gebeurtenissen uit mijn professionele verleden.

2. Ik denk na over wat er in mijn professionele leven gebeurd is.

3. Ik denk aan gebeurtenissen uit mijn professionele verleden.

\section{Heden:}

5. Ik richt me op wat er nu in mijn professionele leven aan het gebeuren is.

6. Ik denk na over waar ik vandaag de dag sta met betrekking tot mijn werk.

\section{Toekomst:}

7. Ik denk na over wat mijn professionele toekomst me te bieden heeft.

8. Ik denk na over de tijd die nog moet komen als werknemer.

9. Ik richt me op mijn professionele toekomst.

\section{Doeloriëntatie}

Antwoordcategorieën: 1 = helemaal mee oneens, 2 = enigszins mee oneens, 3 = eens noch oneens, 4 = enigszins mee eens, $5=$ helemaal mee eens

\section{Leertoenadering:}

1. Ik vind het belangrijk om zo goed mogelijk te begrijpen, waar ik mee bezig ben op mijn werk.

2. Ik wil leren om de dingen die ik op mijn werk doe zo goed als ik kan uit te voeren.

3. Ik wil in mijn huidige baan zoveel leren als maar mogelijk is.

Extra vraag:

4. Ik wil mij zoveel mogelijk ontwikkelen in mijn huidige baan.

Leervermijding:

5. Ik ben vaak bezorgd dat ik op mijn werk niet alles leer wat er te leren valt.

6. Ik maak me zorgen dat ik niet alles uit mijn werk haal wat er voor mij in zit.

7. Soms ben ik bang dat ik de dingen op mijn werk niet zo goed doe als ik wel zou willen.

Extra vraag:

8. Soms ben ik bang dat ik me niet goed genoeg ontwikkel binnen mijn huidige baan. 


\section{Goal orientations and temporal focus of older workers: What is the relation with retirement intentions?}

Maria Peeters, Bert Schreurs \& Jorg Damen, Gedrag \& Organisatie, volume 27, March 2014, nr. 1, pp. 69-89.

The aim of this study was to increase our insight into what older employees motivates to stay active on the labour market. For this we examined if and how the temporal focus of older workers is related to retirement intentions. It was assumed that mastery goal orientations (approach and avoidance) would mediate this relationship. 548 employees older than 45 years participated in the research. Our results showed that past focus was positively related to mastery avoidance goals whereas future focus was positively related to mastery approach goals. Moreover, mastery approach goals were positively related to retirement intentions and mastery avoidance goals were negatively related to retirement intentions. The conclusion is that the stimulation of a future focus as well as a mastery approach orientation play important roles in motivating older employees to work until retirement age.

Key words: temporal focus, goal orientation, retirement intentions, work motivation, older workers 